Article

\title{
Rent-Seeking Practices, Local Resource Curse, and Social Conflict in Uganda's Emerging Oil Economy
}

\author{
Tom Ogwang *(D), Frank Vanclay ${ }^{(}$and Arjan van den Assem \\ Department of Cultural Geography, Faculty of Spatial Sciences, University of Groningen, 9712 CP Groningen, \\ The Netherlands; frank.vanclay@rug.nl (F.V.); a.van.den.assem@rug.nl (A.v.d.A.) \\ * Correspondence: t.ogwang@rug.nl or ogwangtom@gmail.com
}

Received: 27 January 2019; Accepted: 25 March 2019; Published: 27 March 2019

\begin{abstract}
We consider the different types of rent-seeking practices in emerging oil economies, and discuss how they contribute to social conflict and a local resource curse in the Albertine Graben region of Uganda. The rent-seeking activities have contributed to speculative behavior, competition for limited social services, land grabbing, land scarcity, land fragmentation, food insecurity, corruption, and ethnic polarization. Local people have interpreted the experience of the consequent social impacts as a local resource curse. The impacts have led to social conflicts among the affected communities. Our research used a range of methods, including 40 in-depth interviews, focus group discussions, participant observation, and document analysis. We argue there is an urgent need by all stakeholders-including local and central governments, oil companies, local communities, and civil society organizations-to address the challenges before the construction of oil infrastructure. Stakeholders must work hard to create the conditions that are needed to avoid the resource curse; otherwise, Uganda could end up suffering from the Dutch Disease and Nigerian Disease, as has befallen other African countries.
\end{abstract}

Keywords: local resource curse; social conflicts; social impacts; presource curse; rent seeking

\section{Introduction}

Uganda discovered commercially viable oil deposits in 2006 [1-3]. Studies have revealed both positive and negative expectations from the discovery of oil in the Albertine Graben region [4-8]. Many people are expecting that oil production will contribute to increased employment opportunities, higher incomes, improved roads, and improved access to public services [3]. However, the discovery of oil has also come with negative consequences for local people, including rent seeking, social conflict, and a local resource curse, which is similar to the experiences of other oil-producing countries [3,7,9-12]. Many scholars have identified that oil tends to be associated with resource curse issues, including corruption, instability, and economic underperformance [13-24].

The government of Uganda is in the process of commercializing its oil and gas resources. From its discovery in 2006, Uganda's oil and gas sector has been transitioning from exploration and appraisal to the development phase in preparation for full production [25-27]. Oil production licences were issued to the joint venture partners, Total E\&P Uganda, and Tullow Uganda Operations Pty Ltd in 2017, with CNOOC being awarded its licence in 2014. Their licences will run for 25 years, with the possibility of renewal. Two new oil companies, Oranto Petroleum from Nigeria and Armour Energy from Australia, have also been given exploration licences. Two laws were enacted to update the legal framework: the Petroleum (Exploration, Development and Production) Act 2013; and the Petroleum (Refining, Conversion, Transmission, and Midstream Storage) Act 2013. Due to inadequate capacity at all levels, developments in the oil and gas sector are proceeding with only the limited involvement of communities, community organizations, or local government. Tumusiime et al. [26] (p.3) suggested 
that "Uganda's oil and gas sector has been shrouded in secrecy, with minimal engagement of the local and cultural institutions and that information pertaining to the sector is not always readily available, exacerbating feelings of marginalization. Such feelings engender desperation and build favorable grounds for conflict and confrontations between communities, state agencies, and private companies involved in oil and gas activities."

Between 2000-2008, sub-Saharan Africa's natural resource rents increased sixfold [28]. However, Barma et al. [28] (p. 23) noted that new resource-dependent countries "tend to suffer from poor governance and weak institutional capacity, which exposes them in turn to a heightened vulnerability to the resource curse". They observed that, while countries such as Botswana and Chile have been fortunate to benefit from their resources, others such as the Democratic Republic of Congo or Nigeria have not, and have "suffered from decades of poor governance, conflict, and impoverishment, and appear to be on the downward spiral that typifies the conventional understanding of the resource curse" (p. 25). They suggested that "competition over rents, no matter from where they derive, is a central fact of any political economic system. In resource-dependent developing countries, the magnitude of rents can be enormous, making the extractive industries sector itself a key locus of political contestation" (p. 77).

Chakraborty and Dabla-Norris [29] argued that in many developing and transition countries, the relatively wealthy often practice rent-seeking activities rather than engage in productive entrepreneurial activities or other actions that contribute to development. Rent seeking refers to the largely unproductive, exploitative activities that bring personal benefits to individuals but negative outcomes for society, and can take many forms, including: bribery, corruption, smuggling, and black market sales [30]. Scholars [21,31,32] have stressed that having natural resource abundance may not guarantee economic prosperity, although others [28,33] suggested that, if well managed, natural resource endowments can bring development to resource-rich countries.

In the global South [34], especially in Uganda, the discovery of oil will not necessarily guarantee that the country will come out of poverty [35,36], particularly if dubious deals and speculative practices are not dealt with, and if strong systems are not put in place to mitigate negative outcomes and perverse behaviors. With oil developments in Uganda being poorly managed and governed [37], Uganda is likely to join the growing list of resource-cursed countries, eroding its recent achievements and potentially plunging the country into armed conflict and instability [3]. Uganda is likely to suffer from the 'Dutch Disease', which is a situation where natural resource developments negatively affect other sectors of the economy [5]. It is also likely to experience the 'Nigerian Disease', which refers to the squandering of resource revenues [38]. Numerous scholars have pointed out that, if not well managed, the extractive industries can result in the resource curse [3,14,17-23].

Much literature has discussed the (mis)management of natural resources, with considerable focus on the oil curse and its impacts at the national level [39-46]. However, there are only limited studies on rent seeking, the local resource curse, and social conflict, especially as they relate to Uganda's emerging oil industry. Our research contributes to understanding the conditions that foster rent-seeking practices and the local resource curse, and considers how they enhance conflict among the different actors in Uganda's emerging oil industry.

We analyze the impacts of rent-seeking practices, local resource curse, and social conflicts in Uganda's emerging oil economy, with a focus on the local communities in the Albertine Graben region. We argue that in Uganda and other resource-rich countries, all of the stakeholders (including the central and local governments, traditional institutions, local communities, and oil companies) should ensure that all negative consequences are adequately addressed to avoid a future resource curse that would undermine the benefits of oil discovery. The purpose of this paper is to examine how rent-seeking practices lead to a local resource curse and social conflict at the community level. The paper examines rent-seeking practices in the oil-rich Albertine region of midwestern Uganda, analyzes the manifestations of the local resource curse, and examines how the local resource curse leads to social conflict. We discuss the impacts of rent seeking on local communities. We are 
particularly interested in understanding how these practices undermine the community benefits that will potentially arise from oil developments with the view of avoiding and mitigating the resource curse syndrome at the local level.

\section{Methodology}

This paper is part of a larger research project, which began in 2015, examining the impacts of the oil boom on people living in the Albertine Graben region of Uganda [3]. We argue that instead of empowering the local community, the presence of natural resources is disempowering, and makes people more vulnerable to the activities and manipulations of speculators, entrepreneurs, and local leaders, which we consider to be rent-seeking practices, leading to a local resource curse. Rent-seeking practices encompass natural resource governance challenges, including but not limited to land grabbing, corruption, bribery, unfair compensation, and speculation. We define the 'local resource curse' as vulnerability experienced by local communities resulting from the presence or discovery of a natural resource.

Our analysis focused primarily on three risks, and on how these led to social conflict: loss of property, economic displacement, and community disarticulation. Loss of property includes the loss of both individual and community-owned land, as well as housing, crops, and animals, as well as other physical assets. By economic displacement, we mean not only the loss of livelihoods and other sources of income, but also the loss of access to resources and markets, as well as discrepancies between opportunities provided and people's skills and interests [47]. Community disarticulation is where there is a breakdown in social ties and social organization. These three risks arose from our data as the key emerging themes.

We examine whether or not the discovery of oil is a blessing or a curse for Uganda. In addition to an extensive document analysis, the research is based on primary data collected by the lead author between December 2017 and March 2018 in the districts of Hoima, Buliisa, and Kibaale in the Albertine Graben region of Uganda (see Figure 1). These districts were selected because most of the oil activities are concentrated there. Hoima and Buliisa will host infrastructure such as the pads, refinery, pipelines, and processing facilities. Hoima is the official seat and headquarters of the Bunyoro Kitara Kingdom. The communities in Kibaale District have been especially affected by land acquisition.

Our research utilized qualitative data collection techniques, including in-depth interviews, focus group discussions, and field observation. The focus group discussions identified the major issues of concern for local people. This was important background information to guide the in-depth interviews. A total of 52 people participated in this research, including interviews with 17 key informants, and five focus group discussions with five to seven participants per group. The key informants were chosen because of their responsibilities in the various relevant institutions. Four focus group discussions comprised mixed groups of males and females. One focus group was for women only in order to allow women the opportunity to speak freely on matters concerning land and compensation. Other people interviewed included: local government officials, journalists, local leaders, representatives of civil society organizations, the Bunyoro Kitara Kingdom, and members of the local communities. Field observation was undertaken to gain an impression of the region and corroborate claims made by research participants, for example relating to displacement and infrastructure developments. 


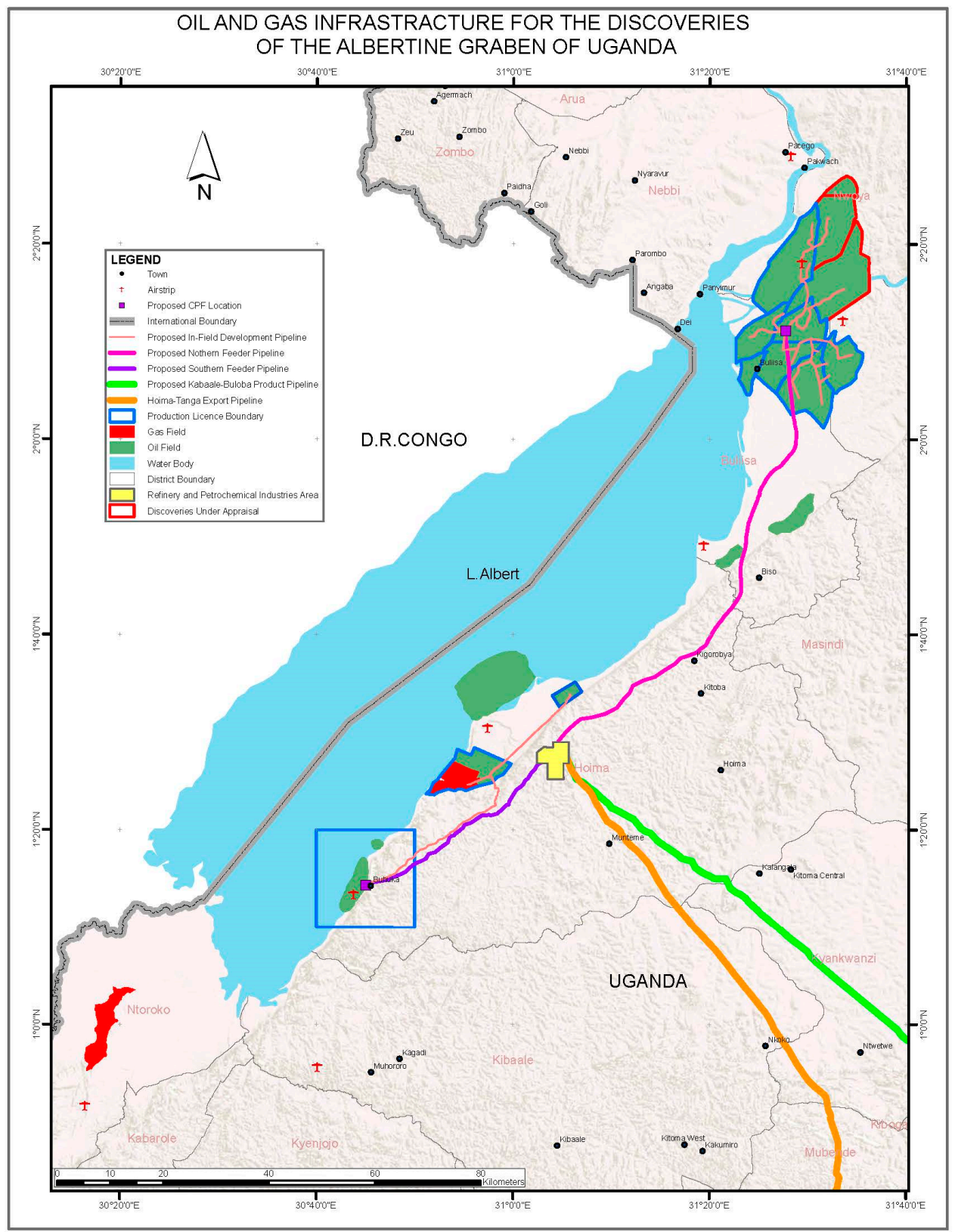

Figure 1. The Albertine Graben Region of Uganda showing oil development. Source: Petroleum Authority of Uganda (2019), https:/ / pau.go.ug/uploads / oai.pdf.

The researchers also reviewed relevant secondary sources. The documents reviewed included oil and gas project reports, government documents, and civil society reports. The documents supplemented our primary data and provided important information on the status and activities of the oil projects in the region. This research took place when the Commission of Inquiry into Land Matters was underway. This commission was initiated in December 2016 and commenced in May 2017, and was headed by Justice Catherine Bamugemereire. The Commission's tasks were to inquire into the effectiveness of law, policies, and processes of land acquisition, land administration, land management, and land registration in Uganda. Our research benefited from the Commission's public hearings and testimonies, especially relating to the 'hot spot' oil districts of Hoima, Buliisa, and Kibaale. During the Commission's visit to Kibaale District, many dubious land transactions were identified, revealing the involvement of district technical officers (surveyors, planners, civil engineers, etc.) and a cabinet minister in inappropriate conduct. 


\section{The Various Stakeholders}

The oil and gas sector has attracted many players ranging from local to national and international actors. A number of think tanks and advocacy organizations have been established. Some-e.g. Advocates Coalition for Development and Environment (ACODE), and the Africa Institute for Energy Governance (AFIEGO) — have been accused by the government of being too critical, biased, and working against the national interest. To prevent the local resource curse, civil society organizations such as AFIEGO, Global Rights Alert, Oil Watch Network Uganda, and Publish What You Pay Bunyoro Chapter, among others, have been active in the region, with many different activities, including organizing a dialogue on the rights and future of project-affected persons. Over 7000 people from 13 villages in Hoima District were displaced by the land taken for the Kabaale Industrial Park, which will be used for the Hoima International Airport, the oil refinery, and other oil-related activities. In 2013, with support from AFIEGO, some dissatisfied individuals took the government to court over what they termed unfair compensation. Non-governmental organizations (NGOs) play an important role in voicing the grievances of affected persons to ensure that they are treated fairly, and that compensation is adequate and payments are made in a timely manner [48].

Religious as well as academic institutions have also been active. Local cultural institutions have been instrumental in shaping debates on oil and gas in their region. The Bunyoro Kitara Kingdom, where most of the oil activity is now taking place, is at the forefront in demanding an equitable share of oil revenue for the kingdom. According to the Public Finance Management Act, "The Government shall grant one percentage point of the royalty due to the Central Government to a gazetted cultural or traditional institution" [49]. This implies that all gazetted kingdoms will share the one percent, but the Bunyoro Kitara Kingdom is not happy with this arrangement.

\section{Rent-seeking Practices and the Local Resource Curse}

The oil and gas industry is characterized by opportunities and governance challenges, which if not addressed properly, provide a fertile ground for rent-seeking activities. According to the communities we interviewed, there were many instances of rent seeking taking place. For example, there were cases of sophisticated land grabbing by some local government and other officials gaining control over community land, obtaining land titles in their own name, and then on-selling the land [46]. Land grabbing "refers to an unprotected practice of obtaining interests in or rights over unregistered land without full disclosure to the unregistered owner(s) of that land" [50] (p. 83). Many allegations of land grabbing came to light during the public hearings and testimonies given in the Commission of Inquiry into Land Matters. For example, the commission found that a former Kibaale District staff surveyor had acquired about 400 hectares, which he later sold to the Uganda Land Commission at a considerable profit [43]. According to Kasozi and Namyalo [51]:

"A Cabinet minister and other senior Kibaale District officials have been named before the Commission of Inquiry into land matters in the alleged fraudulent acquisition of ownership of large tracts of land with the aim of benefiting from Land Fund. The minister and other government officials have been accused of fraudulently procuring land titles for [an] unserveyed (sic) chunk of land belonging to the Kibaale District Land Board... the State minister in charge of Economic Monitoring in the Office of the President, and other district officials paid nominal fees of Shs70,000 [equivalent to USD 20] to acquire certificates of titles for thousands of acres of land in various parts of the district so as to enrich themselves."

Corruption and bribery are common in road projects, especially in relation to land acquisition [47]. According to our participants, during the construction of the Hoima-Kaiso-Tonya Road, officials from the Uganda National Roads Authority claimed extra 'ghost kilometers'. Our participants argued that the actual length of the road was $83 \mathrm{~km}$, not $92 \mathrm{~km}$ as had been stated. This issue also came to light during a 2015 commission investigating corruption in the roads sector, which had also been headed by 
Justice Bamugemereire. According to the Independent [52], these missing $9 \mathrm{~km}$ represented a loss of USD 9 million.

Kolstad and Soreide [53] suggested that "corruption is the main reason why resource-rich countries perform badly in economic terms" (p. 214). They argued that in resource-rich countries, corruption takes two primary forms: rent seeking and patronage. Resources induce patronage, with governments using resource revenues to pay off supporters who help them stay in power. This results in reduced revenues, the inappropriate allocation of public funds, and governance issues in that accountability mechanisms are avoided. Other relevant work on the resource curse at the community level includes the research of Gilberthorpe and Papyrakis [54] and Boutilier [55].

In addition to sophisticated land grabbing and corruption, another issue is unfair compensation rates paid to project-affected persons. According to an interview with a district official in Hoima, many people complained of inadequate compensation. The schedule of payments was determined by the district local government, and approved by the government chief valuer.

A common practice in the region is speculation, which has been largely driven by the need for land for oil and gas development. While some owners can accrue huge returns from land sales or compensation, most project-affected persons are illiterate smallholder peasants living in remote villages. These villagers have limited bargaining power and can easily be taken advantage of or deceived. This problem is exacerbated by the land being communally owned.

\section{Manifestations of a Local Resource Curse}

Our findings suggest there are three ways in which the local resource curse is manifested: loss of property, economic displacement, and community disarticulation.

Loss of property

According to research participants and other sources [56,57], apart from the destruction of property (crops and buildings) and displacement of people, in the construction of the Hoima-Kaiso-Tonya Road, the local resource curse was made worse by delays in the payment of compensation to the project-affected persons. While the construction of new infrastructure is sometimes seen as an indicator of community development, the findings in Hoima indicate otherwise. According to one local community leader:

"Out of the households affected by the oil refinery at Kabaale in Buseruka Subcounty, 93 households opted for resettlement. Those who preferred money were all compensated, although some complained of undervaluation of their land and properties. However, out of the 93 households that opted for resettlement, 46 houses were constructed for them at Kyakabooga parish in Buseruka Subcounty by the government through a construction company called Samadhura Technology Limited. The remaining 47 families are still in the camp at Kabaale waiting to be resettled. This is a real local curse being in Kyakabooga camp, yet one had his own home before the oil was discovered in the area! Besides the resettlement, the process of resettlement affected our cohesion as a community".

Economic displacement

Economic displacement has been experienced by the local population in various ways. There has been increased competition for land, labor, and food. This has had flow-on effects. Given the extent of land-take for oil production, the discovery of oil has decreased agricultural production, which has led to food shortages. However, there are other complexities. For example, the declining agricultural production in Buseruka Subcounty has been attributed by some to land loss and the fragmentation of oil-related activities, while others believe that oil has created opportunities to make quick money, thus enticing people to shift away from agricultural activities. Many youth have abandoned agriculture and moved to urban centers looking for alternative opportunities. According to the Ministry of Energy and Mineral Development [50] (p. 21): 
Since the discovery of oil in the Albertine Graben, speculative buying of land and registration of freehold titles ... has increased significantly in the hope of sharing in the benefits from petroleum production. The discovery of petroleum has increased interest in land in the area, and a number of individuals have started speculating in land. In a context where land administration is poorly developed, speculative land transactions have led to a sharp increase in land disputes.

It was noted that there was high competition for labor, with many farmers finding it difficult to obtain casual laborers willing to work for them. Laborers were asking for higher wages than previously paid, which local communities say they cannot afford. This was attributed to the higher wages paid to workers at the construction sites such as the airport and oil roads, etc. Many people preferred to work for the oil companies and construction firms. There were visible signs of Dutch Disease, especially in Hoima, which had experienced a marked decline in non-oil activities. Many people have high expectations that the oil industry will provide a living for them. This is what Cust and Mihalyi [58] termed the resource curse, a situation where oil discoveries first lead to jubilation and then to economic jeopardy.

Physical and economic displacement have led to increased hardship and food shortages. The displaced families originally had their own crops and gardens, including mangoes, jackfruits, avocado, cassava, and beans, but when they were forced to leave their ancestral land, they were taken to a location where there was no food. This situation was made worse when some people were given land for cultivation far away from the resettlement site. Cropping is the predominant economic activity in the Albertine Graben, with $95 \%$ of the rural population cultivating an average of about a hectare of land. Fishing is the second most important economic activity, providing informal employment (especially for women and youth) in fishing and associated industries such as fish preparation and preservation, transportation, and market sales [50]. Although the Resettlement Action Plan acknowledges fishing as an important source of livelihood, there are no plans to develop alternative livelihoods strategies to address this economic displacement.

Community disarticulation

Large-scale development projects require the displacement of people, and also leads to an influx of people seeking opportunities. This affects the social order and community cohesion in existing local communities in many ways. For example, there will be increasing demand on the limited social services in the area. According to one participant, the population of many small towns in Nyamasoga and Buseruka sub-counties increased considerably, with many people in search of better opportunities, in other words, the 'honeypot effect' [47]. Therefore, it is important that the government adheres to international best practices in land acquisition and resettlement [59], and addresses project-induced in-migration [60]. According to one interviewee:

This [influx] has resulted into competition for the limited resources especially water in Nyamasoga. Water problem has been worsened by the construction of Kabalega Power Station (9MW hydro power plant) located at River Wambabya and electrification extension in Buseruka Sub-county. This power plant has led to competition for water, because it affects the flow of water and uses huge quantities of water. This plant has caused a water crisis in the area, especially during dry seasons. This is a local resource curse, since some of us don't benefit directly from the power generated from this river, because we cannot afford the cost. Besides that, we don't have houses which can be connected to the electricity grid.

Social and gender inequalities have increased. According to some women interviewed, many women cannot apply for certain jobs, such as truck drivers or machine operators, because such jobs are designated for men. This has widened the income gap between men and women. During one focus group discussion, the local population reported that the Kolin Construction Company, which constructed the Hoima-Kaiso-Tonya Road, came with their own workers. The focus group 
participants argued that local people could have done some of this work. They claimed that only a few locals were employed, and these were lower-paid jobs such as controlling traffic.

\section{Local resource Curse and Social Conflicts}

We now consider how the three key manifestations of the local resource curse lead to social conflict. We found that there were many social conflicts at and between many levels, including between the central and local governments and local communities. This was especially the case in Kabaale Parish, where people were displaced to make space for the construction of the airport and oil refinery. Delays in the payment of compensation to people affected by these projects created resentment, anxiety, and fear that they might not be compensated at all. Initially, some residents never wanted to leave their ancestral land, but they were forced to leave, and their houses were destroyed, making them very angry. Another disgruntled group comprised the fisherfolk and others involved in fishing-related businesses. Many of these people lost their livelihoods because of oil-associated activities, especially at the Tonya landing site. The local fisherfolk claimed they were restricted, and in some cases prevented from fishing, thereby denying them the ability to earn a living, hence experiencing the local resource curse. Their dissatisfaction has led to social conflicts.

Conflicts between pastoralists and agricultural farmers have intensified in the villages of Nyahaira, Kitegwa, Bukona, and Kyapuloni in Buseruka Sub-county, because the relocation of many people has put these two groups in competition for land. Conflict has occurred because the pastoralists have grazed their animals in the gardens of farmers, which, according to some residents and the National Association of Professional Environmentalists [61], was a factor contributing to food insecurity. The pre-existing residents claimed the pastoralists had brought in some 300 to 400 head of cattle needing water and pasture, thus creating conflict over resources. When the farmers reported their concerns to the police, instead of obtaining the justice they had anticipated, they were arrested on allegations of injuring some animals belonging to the pastoralists. This has led to the ongoing conflict and polarization of the two groups.

In a focus group discussion at Kiryatete East, Hoima town, participants complained that land conflict was rampant. They identified someone whom they termed a 'land grabber', and accused him of being responsible for mischievously acquiring people's land, especially that of the poor. They allege that this happened with the full knowledge and tacit approval of the local council chairperson, with an implication of bribery and/or coercion. It was claimed that the land grabber had threatened to kill the public officials if they would not sign over the land agreements. Some people lamented that most of the district documents were written in English, given that many of the affected people cannot read or write English. According to a journalist working with a local radio station, the Hoima District Local Government only published the list of property compensation rates in English, which is a language that is not widely understood by many people affected by land acquisition in the Albertine region.

The local transport industry has not benefited from the increased transport demand. Many boda boda (motorcycle taxi) riders complained that the company constructing the airport came with their own vehicles to transport workers. They argued that they had wanted to tender to provide transport services to the company, but they were never consulted. The boda bodas claimed they have even lost customers. In a focus group discussion in Kiryatete West, Hoima town, participants attributed the increased number of accidents to the ongoing oil activities in their area. They claimed that since the construction of the Hoima-Kaiso-Tonya Road, accidents have increased due to an increased number of road users and especially an increased number of heavy vehicles.

Some participants were very bitter that they have been denied the ability to sell their products to the oil companies. According to one participant:

"The oil companies are only interested in registered companies to supply them with local products like tomatoes, chicken, eggs, and many others. We have not been given a chance to sell our products and yet we thought it would give us a chance to sell and get money. They biggest challenge to us is how to mobilize ourselves at the community level to register as a company in order to qualify to supply our 
merchandise. We are also worried about our ability to mobilize the required capital to supply these companies."

Although the region was not restricted to only one ethnic group, the discovery of oil has led to people from many different ethnicities, regions, and cultural backgrounds flocking to Hoima, especially to Buseruka Sub-county. According to one interviewee, the newcomers bring their different cultures and behaviors, and the local people fear that their own cultural practices will be diluted due to this influx. According to the chairperson of a local council, oil activities have brought much congestion to the campsite at Kyakabooga, especially following the displacement of 13 villages to create space for the oil refinery and airport. He observed that these people had families and farm animals, and that space was limited at the campsite. Therefore, big families and/or people with many animals had left the campsite and intruded into neighboring communities, creating challenges for the host communities.

Some schools were closed to make way for the refinery project. The government had promised to construct other schools near the campsite, but this has not yet been done. Therefore, some schoolchildren had to walk five to seven km every day to go to other schools. During the focus group discussion, some participants noted that many schools in the area had been shut down. In some cases, teachers left their jobs after they had received compensation for land loss. Sometimes, the majority of school attendees had been relocated, and the few remaining families with school-age children had to seek alternative schools far away. This affected the children's progress. Some scholars have documented how countries with natural resources tend to invest less in human capital $[21,36]$. It is evident that the land-take for oil and gas-related developments in the Albertine Graben region has contributed to school dropouts, for example, through the relocation of schools to new areas, the displacement of project-affected households, or the impacts of resettlement to new places. According to one government official, during the construction of new schools, all of the teachers were transferred to other schools, and by the time the new schools were completed, there were no teachers left. The Buseruka Sub-county Local Government intervened and recruited three teachers paid by the sub-county.

The allegation that oil activities have led to a decline in school attendance has been rebuked by the government and oil companies. Sebikari [62] argued that the completion of the 91-km tarmac road from Hoima to Kaiso Tonya has made this previously hard-to-reach area easily accessible, assisting in the retention of teachers. She argued that many oil companies have invested in the education sector, improving the quality of education, thus contradicting claims that oil activities were responsible for the dropout of school-going children.

“CNOOC Uganda Limited has since 2012 implemented initiatives to promote education, including the Annual Best Performers Awards for ... students in the district that has attracted 330 beneficiaries.

Total EEP is implementing a scholarship scheme to support top performers from the region in their secondary and university education". [62] (online)

Sebikari [62] noted that challenges such as persistent pupil dropout, inefficient teacher deployment, and teacher absenteeism predate oil and gas activities, and were previously common in many of the rural communities now being supported by the oil companies. She observed that during the acquisition of land for the refinery, two primary schools (Nyahaira and Kyapuloni) were affected. However, the Ministry of Energy and Mineral Development constructed two replacement primary schools, each with 21 classrooms, staff quarters, and water and sanitation facilities. Nyahaira Primary School was relocated next to the resettlement area in Kyakaboga village, while Kyapuloni Primary School was relocated to Katooke village. The sites for these new schools were selected by the community. According to her, "all the above initiatives and more indicate the benefits to children's education arising from oil and gas-related activities".

During one focus group in Kabaale Buseruka Sub-county, some members noted that while some people received compensation, most did not receive financial literacy training. During construction of Hoima-Kaiso-Tonya Road, many of those who were compensated wasted their money on alcohol, 
gambling, and consumer goods. To them, this was a resource curse, since such people lost both their land and the money, and have since been cursing the government and the oil companies for their miseries.

A number of people resisted being displaced in Kabaale Buseruka Sub-county. They were arrested and allegedly tortured by security personnel, with their houses burnt to ashes. According to some community members, torture and suffering amount to a local resource curse. These residents tried to take legal action, but their cases were delayed, and they eventually gave up, believing nobody would help them.

According to one official in the Bunyoro Kitara Kingdom, there is local resource curse in terms of the lack of information sharing by the national government with the kingdoms in the area. As a result, the Bunyoro Kitara Kingdom together with Acholi Kingdom and Alur Kingdom have come out to jointly demand that the government should share more information regarding oil and gas developments with them. He noted that the three cultural institutions have demanded that the oil companies ought to: respect cultural rights, historical and sacred natural sites, cultural norms, and the values and practices of the people; contribute to sustainable livelihood options; and safeguard land, environment, and natural resources, among other things. According to him, although a number of oil companies have been licensed for oil exploration and production in the Albertine Graben region, there is no collaboration between the government and the cultural institutions to ensure the conservation of the biodiversity of the region.

Environmental pollution was also a major issue of the local resource curse in the area. There have been many pollution incidents, especially during construction of the Hoima-Kaiso-Tonya Road, because of blasting, earthworks, heavy machinery use, and air pollution from dust [63].

\section{Conclusion}

We analyzed the impacts of rent-seeking practices, local resource curse, and social conflict in Uganda's emerging oil economy, focusing on communities in the Albertine Graben region. The purpose of this paper was to examine how rent-seeking practices lead to a local resource curse and social conflict at the local community level in Uganda's emerging oil economy. Our research identified rent-seeking practices-including sophisticated land grabbing, corruption and bribery, unfair compensation rates, and speculation - and discussed the consequences of this for the different actors. With the discovery of natural resources, issues of weak governance, corruption, and patronage become more complex. We were particularly interested in understanding how rent-seeking practices undermine the potential benefits from the oil developments for local communities with the view of identifying how the resource curse syndrome might be avoided at the local level.

We also examined how oil development has led to a range of social problems, including land grabbing, land scarcity and fragmentation, food insecurity, corruption, and ethnic polarization, among other problems. These outcomes have been interpreted by local people as a local resource curse, and have led to social conflict among the communities in the Albertine Graben region of Uganda. These practices, which local people considered were 'alien' before the discovery of oil in the region, risk undermining the potential benefits that may accrue from exploitation of oil and gas. We also analyzed the manifestations of the local resource curse as loss of property, economic displacement, and community disarticulation. We examined how the local resource curse leads to social conflicts at the local level. Conflicts exist between different actors, such as between the central and local governments, Bunyoro Kingdom and the central government, local communities and the local government, and within communities. These conflicts lead to disharmony that will be detrimental to the growth and development of the oil and gas industry and to Uganda at large.

We recommend that Uganda and other resource-rich countries ensure that all negative consequences from resource discovery and development are fully identified and addressed. We identified that rent seeking takes many forms. The local resource curse was manifested in land grabbing, the displacement of people, the destruction of their property during land acquisition for 
project infrastructure, inadequate or delayed payment of compensation, changes in agricultural output that lead to local food shortages thus exacerbate social tensions, and conflict among local communities. This indicates that adequate laws that carefully address land acquisition and land ownership issues, especially in terms of customary or communal tenures, are needed. The active involvement of local and religious leaders in preaching peace to communities should be encouraged. NGOs can also play a key role. As a poor country in a conflict-infested region, Uganda should avoid falling prey to the perils of the resource curse, which could lead the country to armed conflict, thereby undermining all of the achievements the country has made up until now. The grievances and concerns of local communities should be taken seriously so that a win-win-win situation is reached by the government, developers, and local communities.

Author Contributions: Conceptualization, T.O. and F.V.; data collection, T.O.; analysis, T.O.; writing—original draft preparation, T.O.; writing—review and editing, F.V. and A.v.d.A.; supervision, F.V. and A.v.d.A.

Funding: This research was funded by Nuffic: the Dutch organisation for internationalisation in education.

Conflicts of Interest: The authors declare no conflict of interest.

\section{References}

1. Balikuddembe, J.; Ardalan, A. Disaster Risk Management and Oil Production in Uganda: Need for a Win to Win Approach. 2014. Available online: http://www.preventionweb.net/english/hyogo/gar/2015/ en/bgdocs/inputs/Balikuddembe\%20and\%20Ardalan,\%202014.\%20Disaster\%20risk\%20management\% 20and\%20oil\%20production\%20in\%20Uganda.pdf (accessed on 26 March 2019).

2. Kuteesa, A. Local Communities and Oil Discoveries: A Study in Uganda's Albertine Graben Region; Brookings Institute: Washington, DC, USA, 2014. Available online: https://www.brookings.edu/blog/africa-infocus /2014/02/25/local-communities-and-oil-discoveries-a-study-in-ugandas-albertine-graben-region/ (accessed on 26 March 2019).

3. Ogwang, T.; Vanclay, F.; van den Assem, A. Impacts of the oil boom on the lives of people living in the Albertine Graben region of Uganda. Extr. Ind. Soc. 2018, 5, 98-103. [CrossRef]

4. Bainomugisha, A.; Kivengyere, H.; Tusasirwe, B. Escaping the Oil Curse and Making Poverty History: A Review of the Oil and Gas Policy and Legal Framework for Uganda; ACODE Policy Research Series No. 20; ACODE: Kampala, Uganda, 2006. Available online: https://www.africaportal.org/documents/9141/PRS_20.pdf (accessed on 26 March 2019).

5. Bategeka, L.; Matovu, J. Oil Wealth and Potential Dutch Disease Effects in Uganda; Economic Policy Research Centre: Kampala, Uganda, 2011. Available online: https:/ /www.africaportal.org/publications/oil-wealthand-potential-dutch-disease-effects-in-uganda/ (accessed on 26 March 2019).

6. International Alert. Governance and Livelihoods in Uganda's Oil-Rich Albertine Graben; International Alert: London, UK, 2013. Available online: http:/ / www.international-alert.org/sites/default/files/publications/ Uganda_2013_OilAndLivelihoods_EN.pdf (accessed on 26 March 2019).

7. Mosbacher, J. Fighting the resource curse: Uganda's pivotal moment. Wash. Q. 2013, 36, 43-54. [CrossRef]

8. Pegg, S. Can policy intervention beat the resource curse? Evidence from the Chad-Cameroon pipeline project. Afr. Aff. 2006, 105, 1-25. [CrossRef]

9. Abiodun, A. Natural Resources and Conflict in Africa: The Tragedy of Endowment; University of Rochester Press: Rochester, NY, USA, 2007.

10. Basedau, M.; Lay, J. Resource curse or rentier peace? The ambiguous effects of oil wealth and oil dependence on violent conflict. J. Peace Res. 2009, 46, 757-776. [CrossRef]

11. Collier, P.; Hoeffler, A. Resource rents, governance, and conflict. J. Confl. Resolut. 2005, 49, 625-633. [CrossRef]

12. Collier, P.; Venables, A. Natural Resources and State Fragility; EUI Working paper, 2010/36; Robert Schuman Centre for Advanced Studies, European University Institute: Florence, Italy, 2010. Available online: http: / / cadmus.eui.eu/ / handle/1814/13860 (accessed on 26 March 2019).

13. Aristide, M.; Moundigbaye, M. Oil and regional development in Chad: Assessment of the impact of the Doba Oil Project on poverty in the host region. Afr. Dev. Rev. 2017, 29, 42-55. [CrossRef]

14. Auty, R.M. Sustaining Development in Mineral Economies: The Resource Curse Thesis; Routledge: London, UK, 1993. 
15. Auty, R.M. Elites, rent-cycling and development: Adjustment to land scarcity in Mauritius, Kenya and Côte d'Ivoire. Dev. Policy Rev. 2010, 28, 411-433. [CrossRef]

16. De Medeiros Costa, H.; dos Santos, E. Institutional analysis and the "resource curse" in developing countries. Energy Policy 2013, 63, 788-795. [CrossRef]

17. Global Witness. The Benefits for Uganda of Joining the Emerging Global Transparency Standard for Extractive Industry Revenues. 2013. Available online: https:/ / www.business-humanrights.org/en/globalwitness-highlights-the-benefits-for-uganda-of-joining-the-emerging-global-transparency-standard-forextractive-industry-revenues (accessed on 26 March 2019).

18. Goumandakoye, H. Oil in Niger: A foundation for promise or a new resource curse? Extr. Ind. Soc. 2016, 3, 361-366. [CrossRef]

19. Hoinathya, R.; Janszky, B. The Extractive Industries Transparency Initiative (EITI): The latest attempt at governing the extractive industries in Chad. Extr. Ind. Soc. 2017, 4, 825-832. [CrossRef]

20. Palazuelos, E. Rentier oil economies and development: Dynamics and varieties. Extr. Ind. Soc. 2016, 3, 564-574. [CrossRef]

21. Pendergast, S.; Clarke, J.; Van Kooten, G. Corruption, development and the curse of natural resources. Can. J. Polit. Sci. 2011, 44, 411-437. [CrossRef]

22. Ross, M. What have we learned about the resource curse? Annu. Rev. Polit. Sci. 2015, 18, 239-259. [CrossRef]

23. Van der Ploeg, F. Natural Resources: Curse or Blessing? J. Econ. Lit. 2011, 49, 366-420. [CrossRef]

24. Zhan, J. Do natural resources breed corruption? Evidence from China. Environ. Resource Econ. 2017, 66, 237-259. [CrossRef]

25. De Kock, P.; Sturman, K. The Power of Oil: Charting Uganda's Transition to a Petro-State; South African Institute of International Affairs: Johannesburg, South Africa, 2012. Available online: https://saiia.org.za/wpcontent/uploads/2013/06/saia_rpt_10_dekock_sturman_20120307.pdf (accessed on 26 March 2019).

26. Tumusiime, D.; Mawejje, J.; Byakagaba, P. Discovery of oil: Community perceptions and expectations in Uganda's Albertine Region. J. Sustain. Dev. 2016, 9, 1-14. [CrossRef]

27. WWF and CSCO. Safeguarding People $\mathcal{E}$ Nature in the East African Crude Oil (EACOP) Pipeline Project: A Preliminary Environmental and Socio-Economic Threat Analysis; WWF and CSCO Research Paper No. 3; WWF and CSCO: Kampala, Uganda, 2017. Available online: https://wwf-sight.org//wp-content/ uploads/2017/07/Safeguarding-Nature-and-People-Oil-and-Gas-Pipeline_Factsheet.pdf (accessed on 26 March 2019).

28. Barma, N.; Kaiser, K.; Le, T.M.; Viñuela, L. Rents to Riches? The Political Economy of Natural Resource-Led Development; World Bank: Washington, DC, USA, 2012. Available online: http://hdl.handle.net/10986/2381 (accessed on 26 March 2019).

29. Chakraborty, S.; Dabla-Norris, E. Rent seeking. IMF Staff Pap. 2006, 53, 28-49. [CrossRef]

30. Krueger, A. The Political Economy of a Rent Seeking Society. Am. Econ. Rev. 1974, 64, 291-303.

31. Torvik, R. Natural resources, rent seeking and welfare. J. Dev. Econ. 2002, 67, 455-470. [CrossRef]

32. Zhuang, Y.; Zhang, G. Natural resources, rent dependence, and public goods provision in China: Evidence from Shanxi's county-level governments. J. Chin. Sociol. 2016, 3, 20. [CrossRef]

33. Su, F.; Wei, G.; Tao, R. China and natural resource curse in developing countries: Empirical evidence from a cross-country study. China World Econ. 2016, 24, 18-40. [CrossRef]

34. Kwasi, D.; Kwesi, A.; David, A. Rent-seeking resource and institutional challenges in Ghana's nascent oil economy. Int. J. Law Manag. 2014, 56, 363-386.

35. World Bank. The Uganda Poverty Assessment Report 2016: Farms, Cities and Good Fortune: Assessing Poverty Reduction in Uganda from 2006 to 2013; Report No. ACS18391; World Bank: Washington, DC, USA, 2016. Available online: http:/ / pubdocs.worldbank.org/en/381951474255092375/pdf/Uganda-PovertyAssessment-Report-2016.pdf (accessed on 26 March 2019).

36. Cockx, L.; Francken, L. Natural resources: A curse on education spending? Energy Policy 2016, 92, $394-408$. [CrossRef]

37. Republic of Uganda. Second National Development Plan (NDPII) 2015/16-2019/20. 2015. Available online: https:/ / consultations.worldbank.org/Data/hub/files/consultation-template/materials/ndpiifinal11.pdf (accessed on 26 March 2019).

38. Williams, A. Shining a light on the resource curse: An empirical analysis of the relationship between natural resources, transparency, and economic growth. World Dev. 2011, 39, 490-505. [CrossRef] 
39. Schilling, J.; Locham, R.; Scheffran, J. A local to global perspective on oil and wind exploitation, resource governance and conflict in Northern Kenya. Confl. Secur. Dev. 2018, 18, 571-600. [CrossRef]

40. Olanya, D.R. Will Uganda succumb to the resource curse? Critical reflections. Extr. Ind. Soc. 2015, 2, 46-55. [CrossRef]

41. Collier, P. The Bottom Billion; Why the Poorest Countries Are Failing and What Can Be Done About It; Oxford University Press: Oxford, UK, 2007.

42. Mbabazi, P.K. The Oil Industry in Uganda: A Blessing in Disguise or an All Too Familiar Curse? Nordic Africa Institute: Uppsala, Sweden, 2013. Available online: https:/ / www.pcr.uu.se/digitalAssets/654/c_654442-1_ 1-k_fulltext01.pdf (accessed on 26 March 2019).

43. Vokes, R. The politics of oil in Uganda. Afr. Aff. 2012, 111, 303-314. [CrossRef]

44. Golder Associates. Environmental And Social Impact Assessment For The CNOOC Uganda Ltd Kingfisher Oil Development, Uganda; Golder Associates Africa: Durban, South Africa, 2018.

45. Nillesen, E.; Bulte, E. Natural Resources and Violent Conflict. Annu. Rev. Resource Econ. 2014, 6, 69-83. [CrossRef]

46. Uganda Land Alliance. Land Grabbing and Its Effects on the Communities in the Oil Rich Albertine Region of Uganda: The Case of Hoima, Buliisa and Amuru. 2011. Available online: http://landgovernance. org/system/files/ULA\%20Land\%20Grabbing\%20Study\%202nd\%20October\%202011.pdf (accessed on 26 March 2019).

47. Vanclay, F. Project-induced displacement and resettlement: From impoverishment risks to an opportunity for development? Impact Assess. Proj. Apprais. 2017, 35, 3-21. [CrossRef]

48. International Alert. Harnessing Oil for Peace and Development in Uganda; International Alert: London, UK, 2009. Available online: http:/ / www.international-alert.org/sites/default/files/publications/Harnessing Oil_for_Peace_and_Development_Uganda.pdf (accessed on 26 March 2019).

49. Government of Uganda. Public Finance Management Act; UPPC: Entebbe, Uganda, 2005.

50. MEMD. Land Acquisition and Resettlement Framework: Petroleum Development and Production in the Albertine Graben; Ministry of Energy and Mineral Development: Kampala, Uganda, 2016. Available online: http: / / petroleum.go.ug/uploads/resources/Jan2017FinalLARFEndorsed.pdf (accessed on 26 March 2019).

51. Kasozi, E.; Namyalo, J. Minister Atwooki named in Kibaale land grabbing saga. The Daily Monitor. 17 March 2018. Available online: http:/ / www.monitor.co.ug/News/National/Minister-Atwooki-named-Kibaaleland-grabbing-saga- /688334-4343518-pcrfalz/index.html (accessed on 26 March 2019).

52. The Independent. UNRA officials created 9 'ghost' kilometres on Hoima-Kaiso-Tonya Road. 27 July 2015. Available online: https:/ / www.independent.co.ug/unra-officials-created-9-ghost-kilometres-hoima-kaisotonya-road/ (accessed on 26 March 2019).

53. Kolstad, I.; Soreide, T. Corruption in natural resource management: Implications for policy makers. Resources Policy 2009, 34, 214-226. [CrossRef]

54. Gilberthorpe, E.; Papyrakis, E. The extractive industries and development: The resource curse at the micro, meso and macro levels. Extr. Ind. Soc. 2015, 2, 381-390. [CrossRef]

55. Boutilier, R.G. Raiding the honey pot: The resource curse and weak institutions at the project level. Extr. Ind. Soc. 2017, 4, 310-320. [CrossRef]

56. Imaka, I.; Musisi, F. Oil Refinery: Residents Reject Government Pay. Sunday Monitor, 6 October 2013.

57. Global Rights Alert. Acquisition of Land for the Oil Refinery: Tracking Progress in Resettling Project Affected Persons Who Opted for Land for Land Compensation; Global Rights Alert: Kampala, Uganda, 2015. Available online: https://globalrightsalert.org/sites/default/files/GRA_Resettlement_Report.pdf (accessed on 26 March 2019).

58. Cust, J.; Mihalyi, D. The presource curse: Oil discoveries can lead first to jubilation then to economic jeopardy. Financ. Dev. 2017, 54, 36-40.

59. IFC. Guidance Note 5: Land Acquisition and Involuntary Resettlement; International Finance Corporation: Washington, DC, USA, 2012. Available online: https:/ /www.ifc.org/wps/wcm/connect/ 4b976700498008d3a417f6336b93d75f/Updated_GN5-2012.pdf?MOD=AJPERES (accessed on 26 March 2019).

60. IFC. Projects and People: A Handbook for Addressing Project-Induced In-Migration; International Finance Corporation: Washington, DC, USA, 2009. Available online: http:/ / documents.worldbank.org/curated/en/ 415141468176677099/pdf/626310PUB0Proj00Box0361488B0PUBLIC0.pdf (accessed on 26 March 2019). 
61. NAPE. Women-Led Action Oriented Research on the Negative Impacts of Oil on Women's Rights, Land and Food Sovereignty in Uganda's Oil Region 2015/2016; National Association of Professional Environmentalists: Kampala, Uganda, 2016. Available online: http:/ / oilwatchafrica.org/static/media/uploads/attachments/ women_led_action_-oriented__report.pdf (accessed on 26 March 2019).

62. Sebikari, G. Oil Activities Boost Education Sector. Daily Monitor. 7 March 2018. Available online: https: / / www.monitor.co.ug/OpEd/Letters/Oil-activities-boost-education-sector / 806314-4330932rcyua/index.html (accessed on 26 March 2019).

63. Kasimbazi, E. Environmental regulation of oil and gas exploration and production in Uganda. J. Energy Nat. Resources Law 2012, 30, 185-221. [CrossRef]

(C) 2019 by the authors. Licensee MDPI, Basel, Switzerland. This article is an open access article distributed under the terms and conditions of the Creative Commons Attribution (CC BY) license (http:/ / creativecommons.org/licenses/by/4.0/). 